\title{
Global Citizenship Education in the Current Era of Migration Crisis and Growing National Values
}

\begin{abstract}
Anna Mravcová
Slovak University of Agriculture in Nitra, SK

MRAVCOVÁ, A.: Global Citizenship Education in the Current Era of Migration Crisis and Growing National Values.

Philosophica Critica, vol. 3, 2017, no. 1, ISSN 1339-8970, pp. 17-28.

Global citizenship represents still more important and rapidly emerging phenomenon, acting mainly in the context of global education as one of its most important pillars. This entire system has been rising mainly in the context of deepening world globalization and still more intensive global problems, which require global knowledge and solutions on a global level. The popularity and relevance of this new approach have begun to grow and gain still bigger importance during last years and the emphasis has been still more placed on the education of global citizens. However, there are also contradictory feelings and moods, resulting from the fear and from the global threat of terrorism, which afforce national feelings and the need to protect mainly what is one's "own", in many people. Therefore, the aim of this paper is to specify the concept of citizenship, as well as to analyse the global citizenship phenomenon and define its importance in the current global society. On the basis of synthesis of received knowledge the paper will explore possible negative impacts or threat of global citizenship to the national identity or affiliation to particular national entity in the current era of migration crisis and growing national values.
\end{abstract}

Key words: Global citizenship - Global education - National citizenship - Migration crisis

\section{Introduction}

Not so long ago people were dealing only with one term denoting citizenship and it was the national citizenship. This concept is generally characterized as a relatively permanent legal bond between the personal entity and the State, resulting in a complex of mutual rights and obligations of the citizen and the State, which 
are determined and secured by the State and enable the citizens to participate actively on the political, governmental, economic and cultural life of the state and society (Ministerstvo vnútra SR 2016), of which the citizenship they have. Accordingly, citizenship is understood as a legal and political status of the individual towards the particular state entity. The creation of the citizenship concept was very lengthy. The shaping of its content had lasted for several centuries and it was also necessarily associated with the formation of national states, the nation right to self-determination, the people's effort to identify themselves with a certain group of people, and also with the parallel effort to diversify themselves from the others. However, as history shows, the creation of closed social units, as well as separating and determination of the groups of people, who are connected by nationality and relevance to some particular State, led to the formation of extreme nationalism. In the end, this also brought the two most devastating wars, which the world has gone through so far. Therefore, after the Second World War, in a region that was a causer of these disasters, in the effort to prevent further ones, the processes for reconnection of the States and the effort to suress the national nationalisms have started, by creating greater entity, irrespective of national differences. The primary goal was to integrate large numbers of people and give them a sense of belonging to something far beyond the limits of their national states. In the late 20th century there was created also a space for emergence of a new citizenship form - supranational citizenship - which was first-time officially enshrined in the Treaty on European Union. The European citizenship currently connects over 500 million people and merges them under the common features (Statista 2016). However, it is still a kind of legal status that binds individuals to some regional grouping and, on the basis of national identity, it provides certain outreach rights as the benefit of membership in this entity.

The citizenship concept did not stay only in these dimensions and it has begun to reach the global level. Because citizenship itself represents phenomenon that has a great unifying power and can deeply connect people with a certain social entity. Therefore, in the context of deepening globalization and increasing global problems the so-called 'Global Education' has begun to develop and it brought a new concept - global citizenship - as one of the main pillars of this new educational system, that extends the concept of citizenship for the whole world.

\section{Insight onto the Phenomenon of Global Citizenship in the Contemporary World}

Current world is strongly interconnected. Globalization is a complex process and it affects everything. The world strategies have been changing within the globalization and the strategy of societal change shall face new challenges (Lysý 2016). 
The very concept 'global' has become still more important today. We can look at global dimension and understand it, according to McGough and Hunt (2012), as something that "connects the local, national and global in a way that people are aware of how their actions have implications for others across the globe" (McGough - Hunt 2012, 1-2). In this context, global education allows people to penetrate into the complex of global issues and examine the links between their lives and the lives of people, places and issues around the world through education. People must understand that they are also part of a global entity that has no internal boundaries and it is not defined by nationality. They must understand that they are global citizens. According to Bourn (2014), people have to acquire the skills to live and work anywhere in the world today. This highlights the need for global education and education for global citizenship, because they change the curriculum make it more relevant for the life in today's world as well as for the global challenges. It is a lifelong process, to aim of which is to equip people with the knowledge to understand the economic, political, social and environmental processes globally, with developing critical thinking and acquirimg identity of global citizen. At the same time, it leads them to assume responsibility for their actions and adopt the basic values of the active global citizenship (Slovak NGDO Platform 2012).

Global citizenship should help to shape a more just and sustainable world through global citizens. According to UNESCO it also helps to increase a sense of shared responsibility, fairness, solidarity, empathy, curiosity and respect for diversity, especially among young people. Thanks to this, people are able to reach new approaches, think critically and be actively involved in the complex of global problems and on their active solving. As long as these problems endanger that huge entity to which they all belong (whether they want it or not), education for global citizenship actually highlights essential functions of education related to the formation of citizenship in relation with globalization. It inspires action, partnership, dialogue and cooperation through various forms of education. It applies also a multifaceted approach employing concepts, methods and theories from related fields, including human rights education, peace education, education for sustainable development and education for international understanding. It promotes an ethos of curiosity, solidarity and shared responsibility (UNESCO 2014). Global citizenship has become an important concept in the current educational system, also because it supports personal "respect and respect for others, wherever they live. It encourages individuals to think deeply and critically about what is equitable and just, and what will minimise harm to our planet. Exploring global citizenship themes helps learners grow more confident in standing up for their beliefs, and more skilled in evaluating the ethics and impact of their decisions" (Ideas for Global Citizenship). 
On the basis of above mentioned definitions, we can say that "global citizen is someone who identifies with being part of an emerging world community and whose actions contribute to building this community's values and practices" (Israel 2013). Being global citizen is a kind of internal feeling and self-identification with a particular system of moral values. Therefore, we usually understand global citizenship as the idea that humanity forms one large community, which should be based on understanding, solidarity, cooperation and mutual help. People, as global citizens, should be able to assume shared responsibility for the development and operating of global society.

There is also a deeper idea about global citizenship, which goes beyond the traditional view that we all are citizens of the world, to the understanding that we have responsibility not only for each other and for what we have created, but also for what was given to us - for the life on Earth (Špirko 2011). In this sense, global citizenship is mainly "a way of thinking and behaving. It is an outlook on life, a belief that we can make a difference" (Young - Commins 2002,1).

\section{National versus Global}

Although the phenomenon of global citizenship has become still more expanded and its importance in today's globalized era is, in order to ensure the sustainability of the world, undeniable, it is a very heterogeneous concept, with a number of perspectives and views in a "range from the idea that everyone is a citizen of the globe to the standpoint that in a legal sense there is no such thing as a Global Citizen" (Young - Commins 2002, 1). Thus, despite the current extent of globalization, this concept is not clearly and positively accepted by everyone. Most critics still associate the concept of citizenship only with the national, maximally supranational (but clearly regionally defined) level. At the same time, on this basis, the concept of global citizenship could be even perceived as a sort of threat in the process of extrusion of national values and national identity to the background, in favor of implementing global thinking, global feeling and global behavior. This negative approach was typical rather for opponents of globalization and global perception, and supporters of the national division of the world. However, recently, because of rising problems and unwilling situations or events in the world, it has become frequent even among ordinary, ideologically neutral, people. Therefore, so hardly and slowly built concept of global citizenship has become still more questionned, fearful and damned. The problem and epicenter can be found in many negative events, which have been shaking intensively various parts of the world today.

An example can be very clearly seen in Europe that represents in the long term stable, tolerant and open space. However, Europe experienced big quakes in its 
foundations recently. It is a continent with the highest concentration of different cultures, consisting of many different nations, which have lived in peace for decades and which are connected under the European Union motto "Unity in Diversity". Europe, in favor of "global good", wanted to leave its old nationalist approach and address oneself to much larger units and their benefit. However, two huge and highly interconnected problems entered into her way and keep agitating Europe even today. These problems have started the strengthening of national feelings in many people again, particularly Europeans who feel they need to protect something they trat as their "own".

The first problem is immigration. Europe had an experience with some level of immigration for nearly all of her history. The extreme situation has started in 2015, when more than million migrants came to Europe. This has started a longlasting migration crisis, which has brought also many new problems and challenges for Europe (more in St'ahel 2016). This problem has begun to split Europe into several opposing camps. We can also watch the endangering of a long time built European and also still emerging global unity. The inflow of migrants crashed to the point of capacity limit long ago. This mass migration arose to a problem of unprecedented proportions with farreaching consequences. However, the biggest problem of the migration crisis consists of the cultural and especially religious differences of absolute majority of the refugees, which encourage the rise of worries in the old "Christian" Europe. Migration crisis has affected substantially the entire continent and even after more than one year, it is not under control.

Regarding the huge masses of refugees, which are coming to European countries, (and these countries are not able to manage them in such a short period of time), the temporary conditions were created. However, those evoke the dislike of refugees by local population, because they do not like the high number of immigrants and the enormous attention which is given to them. All this has a lot of reasons, mainly the disturbances, moving finances to the refugees, taking care about "strangers" instead of "own people", enforcement of different cultural and religious values, restriction of personal freedom of domestic inhabitants, and many others ${ }^{1}$. So, apart from the fact that Europe has a lot of large groups of strong nationalists from earliest recorded time, today also many other (up to now tolerant and open) people have been acquiring the feeling of the need to protect their own social units from the foreign cultural and religious elements (and their often aggressively perceived broaching). This creates and strengthens the national feeling and it has been extending onto large groups of people.

${ }^{1}$ See more in (St'ahel 2016). 
The second big problem is strongly associated with the first one. It is a threat with which Europe had almost no experience in the past. This problem did not belong to the European continent. It is a threat of real terrorism. Despite the fact that in several European countries millions of habitants with a Muslim faith had lived up to the break out of the migration crisis (mainly Germany, France and United Kingdom) the problems of terrorism were mostly unknown in Europe ${ }^{2}$. However, in the end of 2015, Europe has experienced her first, and unfortunately not the last, real terrorist attack. It was launched against the people who were largely open for others in the effort to help refugees in their bad situation and give them a new home. But the attack in Paris in November 2015 hit the whole Europe. It turned out that it is impossible to prevent the members of terrorist organizations enter the Europe at this level of mass immigration. This attack has also started a stronger polarization of domestic inhabitants to those who want to accept refugees among themselves and help them in escaping from the threat of the death, and to those who are afraid of refugees and see a huge threat in them. This deepens their xenophobia, religious intolerance, national feelings and the need to protect their countries - their regions - their Europe. Global feeling and the need to solve global problems of the world and humanity skip into the background and people started to be more enclosed in their national and regional boundaries again.

But the consequences are even bigger. Due to the ongoing problems and crises, there is an increase of negative moods towards the global education, global citizenship concept and the need to solve global problems in many Europeans. People feel more the need for a stronger connection with their own state and nation. More often they are even afraid that the enthusiasm for global education, inclusion of people among global citizens and fostering of global problems, can be a threat to national feelings, national values and ultimately to national security.

\section{Global Citizenship - the Treat or Necessity}

The events in contemporary world increasingly contribute to the people's fear of losing national identity or estrangement of their cultures and national values. This can lead to the formation and growth of the fear of the global and also to the closing up towards the global issues and everything connected with it. In particular, we can see the rejection or contemptuous approach to the phenomenon which has been still just slowly formed in most countries. This trend can be seen in the countries where the system of global education is well developed and

2 Excepting the attacks in 2004 in Madrid, 2005 in London and at the beginning of 2015 in Paris. 
it has a fixed place there, as well as in the countries where it is only at the beginning and it has just started getting into the public awareness. In both there can grow the fear that this very approach can contribute toward many catastrophes in the civilized world and that it also tries to make people recede from their own nations. But does the adoption of global citizenship approach itself really threaten the national citizenship, national values, national feelings or nationality of the people? Are the worries from the fear that the global citizenship pulled us off the national truly legitimate? Would the education for global citizenship bereave us of our national affiliation? People should try to find the answers to all above mentioned questions before they reject the opportunity to be responsible global citizens because of the fear from spurious consequences of this attitude.

The fact is that the world is deeply globalized and the increasing interconnecttedness of the world and its impact is still unknown for most people. Respectively, people still usually do not receive sufficient information to understand not only the interconnectedness of the world, but also its consequences. Because of this it is necessary to implement global education into the systems of individual countries and provide necessary information to general public, so that they will be able to take personal and relevant attitude. They should be able to decide how they will behave and whether they want to accept themselves in the role of global citizens. As Andreotti claims, responsible "education in current 'global times' requires a deeper understanding of the social, cultural, economic and historical forces and flows that connect peoples, places, spaces and world views, and of the difficulties of intervening in complex and dynamic systems" (Andreotti 2014,33 ). Otherwise the educational outcomes tend to unintentionally reproduce unequal relationships between groups of population, simplistic rationalizations of inequality, and instrumental and ethnocentric imaginaries of global citizenship, diversity and social responsibility (Andreotti 2014). Therefore, global education and education of global citizens are considered to be one of the answers to the challenges of the new global economic and social environment (Svitačová Pechočiak 2014).

The main goal is that people will not be disoriented and they will understand also the affiliation they have. They should be interested in the outside world and understand that the global problems are connected with the local ones and therefore they can affect any country of the world (also their own). The education for global citizenship is about understanding that global problems are our concern and also about responsibility of everyone towards these problems (TASR 2015).

Many Western countries have already implemented this system and they teach people towards global responsibility through various ways. Other countries, mostly countries of the Global South, still often refuse this system. They consider it as an extrusion of western values and as belittlement of their traditions (TASR 
2015). Many other countries are not definited against this system so strongly, but they struggle with their own problems and so the global ones do not receive so much attention there. In these countries, people are usually not sufficiently informed about the global issues and they have a feeling that the global problems are not connected with them in any way. However, the global problems are not only problems of the West. Everyone must understand her share of responsibility. For this reason, if we want the global peace we need global citizens, common view and basis with similar values. Global education, either education for global citizenship, does not lead to the suppression of national feelings and does not want to destroy national values in people or delete their national affiliation. Contrawise, the entire global education necessarily links the personal, local, national and global (Globálne vzdelávanie 2016). It is just the national level in the education to global citizenship, from which it is necessary to start and which is essential in the process of building the entire global education system and transformation to global citizens. The national level must never be erased even after the adoption of global values. People must always have the feeling and the awareness that they belong somewhere - to some specific entity - whose common values all members share. They identify themselves with this entity and through this entity they should acquire thus new approaches and critical thinking. They must know and also feel that they are not alone in it. Global citizenship does not aspire to destroying the national affiliation of the people, because it is the basis for creation of responsible active citizens who are also part of something bigger. Then they will see that they should protect not only their individual countries, but also the bigger entity.

The education to citizenship is necessarily linked to the education to global citizenship. As even the author Goňcová states, education to democratic citizenship is a certain intersection of the following subjects and concepts - the concept of civic education, human rights education, intercultural education, peace education and, last but not least, global education (Goňcová 2007, 85). Therefore, the global issues can not be excluded from this education today. Similarly, also Korim emphasizes that today it is almost a necessity to take a comprehensive approach to the education to democratic citizenship, which should reflect current trends and developments, and not only, for example, within the European Union, but also within the wider global contexts (Korim 2013). After all, as one of many common characteristics states, the concept of citizenship expresses the civilized way of incorporating individuals into the social entity (Surmánek - Gbúrová - Dudinská $2003,228-229$ ) and today absolutely not excluding the global entity. 


\section{Results and Recommendations}

At the end of our discourse about the possible negative impact of global citizenship and its education on the national citizenship, national feelings and national values, it is necessary to emphasize that the most important tool for the forming of full-valued citizens in any educational system is the education for citizenship ${ }^{3}$. It has and always will have its unsubstitutable place there as it provides a basis for forming relationship with some social entity for the people. Today just because of deepening globalization we can see increase of the need for laying emphasis also on the global dimension of this education. Therefore, not only teachers and experts, but also the other members of society have a unique opportunity and a great responsibility to prepare people to become responsible citizens also in a global scale (Bourn 2006). But this is not in conflict with national citizenship and national feeling. It is just the necessity to make the world sustainnable. Global issues have become an essential part of our lives as well as the national ones and they cannot be avoided or be mutually exclusive. Knowledge has to be broadened and people should be able to connect their lives with the lives of others, with the problems of our planet, and share the joint responsibility for its sustainability. Solution at the governmental level is not enough. It is necessary to move the system closer to the citizens. Interconnectedness with global issues is still unknown for many people and it is so especially because the current system is not able to prepare them adequately. Therefore, everyone has to have the access to the information and knowledge to be able to take his own attitude, as well as to see that everyone can make a change (both positive and negative), and decide if and what kind of global citizen he or she will be. We can say that global citizenship actually creates some kind of a new social ideal that complements often missing sense of social responsibility for people and their actions.

The answer to the question if there are some negative impacts of global citizenship phenomenon and global education system onto the national identities of the people is quite clear. As we found out, the national level is the basis in the education of global citizens and it can not be abandoned even after the adoption of the global citizenship approach. However, it depends also on the individual approach of each person. There can be found people who consider national identity dangerous and they live only for being active global citizens. It is extremism which can be unfortunately seen in every issue. This extreme approach also causes that many other people are afraid of "global" in this uncertain world. But if we look at the theory and if we also explore the possibilities and duties of global citizenship we understand that the national level is the starting point and it will

${ }^{3}$ See more in (St'ahel 2012). 
be still the fundament on which the global dimension should be built. As we found out, people need to acquire appropriate information, knowledge and skills. To receive valuable, relevant and maximally undisturbed information it is necessary to implement global education and global citizenship education across the educational system of every country of the globe. As it was mentioned, if this will be missing in systems of the contemporary globalized era the sustainability of the world is endangered and very questionable. There is no real reasonable threat coming from global citizenship towards the national identities and values. On the contrary, there is a big threat coming from extreme national approaches towards the globe and our Earth.

Global citizenship represents a cross-cutting issue. It should constitute some kind of moral basis that would be implemented across the entire system, involving everyone (students, teachers, parents, government, broad society). Much like the national citizenship with a corresponding education. Education for national citizenship and education for global citizenship should be taught together today to know how to act actively in national and also global scale. In this respect also the new demands on teachers have been emerging because a successful approach to these issues requires an open mind of teachers, their ability to see this interconnectedness, as well as their openness towards new sources and teaching methods. For this reason much attention is focused on the preparation of so called "global teachers" in many different educational institutions today (Svitačová Mravcová 2014), teachers who understand the fundament of the global issues and would be able to pass it to others adequately.

\section{References}

ANDREOTTI, V. (2014): Critical and Transnational Literacies in International Development and Global Citizenship Education. In: SISYPHUS - Journal of Education, 2 (3), 32-50.

BOURN, D. (2006): Students as Active Global Citizens. London: Development Education Association. Web. 30. Nov. 2016. <www2.warwick.ac.uk/newsandevents/events/ac21/gsi_bournd_students_as_active_global_citizen.pdf>. BOURN, D. (2014): The Theory and Practice of Global Learning. In Research Paper No.11 for the Global Learning Programme. London: Development Education Research Centre.

European Commission. (2015): Standard Eurobarometer 83. European Citizenship. European Union. Web. 8. Dec. 2016. <http://ec.europa.eu/public_opinion/ archives/eb/eb83/eb83_citizen_en.pdf >.

Globálne vzdelávanie. (2016): Global Citizens for Change. Web. 11. Dec. 2016. <http://www.globalnevzdelavanie.sk/co-je-gv> OZ Človek v ohrození. 
GOŇCOVÁ, M. (2007): Od výchovy k demokratickému občianstvu ku globálnej výchove. In: Lysý, J. (ed.): Globálne rozvojové vzdelávanie. Bratislava: ALBUM, 81-91.

IDEAS FOR GLOBAL CITIZENSHIP. (2016): What is Global Citizenship? Scotland: The International Development Education Association of Scotland. Web. 29. Nov. 2016. <http://www.ideas-forum.org.uk/about-us/global-citizenship>.

ISRAEL, R. (2013): What Does It Mean to Be a Global Citizen. OpenDemocracyUK. Web. 4. Dec. 2016. <https://www.opendemocracy.net/ourkingdom/ron-israel /what-does-it-mean-to-be-global-citizen>.

KORIM, V. (2013): Výchova k demokratickému občianstvu v kontexte globálneho rozvojového vzdelávania. In: Lapinová, E. - Korimová, G., (eds.): Determinanty sociálneho rozvoja: sociálna ekonomika ako priestor podpory európskeho občianstva: zborník vedeckých štúdií. Banská Bystrica: EF UMB. Web. 30. Nov. 2016. <http://www.ef.umb.sk/dsr_2013/pdf/Korim.pdf>.

LYSÝ, J. (2016). Revolutions and Preventive Democracy in the Age of Extremes. In: Philosophica Critica, 2 (1), 23-32.

McGOUGH, H. - HUNT, F. (2012): The Global Dimension: A Practical Handbook for Teacher Educators. London: Development Education Research Centre.

MINISTERSTVO VNÚTRA SR. (2016): Štátne občianstvo. Bratislava. Web. 30. Nov. 2016. <http://www.minv.sk/?statne-obcianstvo-1>.

SLOVAK NGDO PLATFORM. (2012): National Strategy for Global Education 2012 2016. Bratislava: MVRO. Web. 8. Dec. 2016. <https://www.mvro.sk/sk/ekniznica/category/1-dokumenty?download=1015: national-strategy-forglobal-education-2012-2016>.

STATISTA. (2016): European Union: total population from 2006 to 2016 (in million inhabitants). [Online.] Web. 8. Dec. 2016. <http://www.statista.com/ statistics/253372/total-population-of-the-european-union-eu/>.

SŤAHEL, R. (2012): Výchova k občianstvu ako problém politickej filozofie. In: Čupková, L. - Skačan, J. (eds.): Filozofia, kultúra a spoločnost'v 21. storočí. Nitra: FF UKF, 83-90. CD-ROM.

SŤAHEL, R. (2016): Environmental Limits of Personal Freedom. In: Philosophica Critica, 2 (1), 3-21.

SURMÁNEK, Š. - GBÚROVÁ, M. - DUDINSKÁ, I. (2003): Politológia (vybrané kapitoly). Prešov: Slovacontact.

SVITAČOVÁ, E. - MRAVCOVÁ, A. (2014): Implementation of Global Development Education into the Curriculum at the Faculty of Economics and Management, Slovak University of Agriculture. In: International Journal of Development Education and Global Learning, 6 (2), 43-61.

SVITAČOVÁ, E. - PECHOČIAK, T. (2014): Výzvy v novom globálnom ekonomickom a spoločenskom prostredí pre globálne rozvojové vzdelávanie na economic- 
kých fakultách. In: Kvalifikácia pre budúcnost'. Košice: Technická univerzita, $272-278$.

ŠPIRKO, D. (2011): Biocentrizmus, humanizmus, zodpovednost'. In: (Úvahy) O biocentrizme a humanizme. Proceedings of a symposium held at the Technical University, Zvolen, 7. september 2011. Zvolen: FEE TU, 12-19.

TASR. (2015): Expertka UNESCO: Extrémizmu sa dá zabránit' už v škole.

Web. 12. Dec. 2016. <http://spravy.pozri.sk/clanok/Expertka-UNESCO:-Extremizmu-sa-da-zabranit-uz-v-skole/385532>.

UNESCO. (2014): Global Citizenship Education. Preparing Learners for the Challenges of the $21^{\text {st }}$ Century. Paris: UNESCO.

YOUNG, M. - COMMINS, E. (2002): Global Citizenship: The Handbook for Primary Teaching. Cambridge: Oxfam.

This paper is a partial presentation of results of the project 03-GA SPU-16 "The Support of Implementation Global Citizenship Education in the System of Global Education at the FEM SUA in Nitra".

\section{PhDr. Anna Mravcová, PhD.}

Department of Social Sciences

Faculty of Economics and Management

Slovak University of Agriculture in Nitra

Tr. A. Hlinku 2

94976 Nitra

Slovak Republic

mravcova.anna@uniag.sk 